\title{
ANALISIS PENGARUH BUDAYA ORGANISASI DAN KEPUASAN TERHADAP KINERJA KARYAWAN (Studi Kasus KSPPS Dana Ukhuwah)
}

\author{
Anton Hiondardjo, Waffa Mutia Mutafannin \\ notna.ah@gmail.com,waffamutia@gmail.com \\ Sekolah Tinggi Ekonomi Islam SEBI
}

\begin{abstract}
This study aims to find out how the influence of organizational culture and satisfaction on the performance of employees at KSPPS Dana Ukhuwah. This study uses correlative or correlational models with the quantitative type of qualitative research. Based on the primary data in the form of questionnaires distributed to employees and secondary data in the form of journals, books and etc. By using Multiple Linear Regression analysis, it can be seen the effect of each independent variable on the dependent variable partially and the effect of independent variables on the dependent variable simultaneously. Based on the results of the analysis of this study, organizational culture variables have a positive and significant influence on employee performance partially and conversely the satisfaction variable does not have a positive and significant effect on employee performance. However, simultaneously organizational culture and satisfaction have sufficient influence on employee performance.
\end{abstract}

Keywords: Organizational Culture, Satisfaction, Employee Performance

\section{PENDAHULUAN}

Salah satu aspek yang sangat penting. Bukan hanya dalam kuantitasnya namun juga dari segi kualitasnya. Jumlah sumber daya manusia di Indonesia yang besar, apabila dapat didayagunakan secara efektif dan efisien akan bermanfaat untuk menunjang laju pembangunan nasional yang berkelanjutan. Agar dalam masyarakat tersedia sumber daya manusia yang handal diperlukan pendidikan yang berkualitas, penyediaan berbagai fasilitas sosial dan lapangan pekerjaan yang memadai. Tantangan utama yang sesungguhnya adalah bagaimana dapat menciptakan sumber daya manusia yang dapat menghasilkan kinerja optimal untuk mencapai tujuan suatu perusahaan atau organisasi. 
Douglas menjelaskan bahwa perusahaan membutuhkan karyawan yang mempunyai kinerja (job performance) yang tinggi. Memiliki sebuah sumber daya manusia yang berkualitas dan kinerja tinggi merupakan sebuah keuntungan besar bagi perusahaan. Sumber daya manusia yang memiliki kinerja yang tinggi dapat membantu perusahaan dalam menggapai tujuan perusahaan tersebut. ${ }^{1}$

Susanto mengatakan untuk menciptakan kinerja karyawan yang efektif dan efisien demi kemajuan organisasi maka perlu adanya budaya organisasi sebagai salah satu pedoman kerja yang bisa menjadi acuan karyawan untuk melakukan aktivitas organisasi. Setiap organisasi maupun perusahaan akan berusaha untuk meningkatkan kinerja karyawan untuk mencapai tujuan organisasi yang telah ditetapkan. Banyak perusahaan atau organisasi yang mencoba berbagai cara untuk meningkatkan kinerja karyawan menjadi lebih efektif dan efisien, misalnya melalui pendidikan dan pelatihan, pemberian kompensasi dan motivasi, serta menciptakan lingkungan kerja yang baik. Menurut Sarplin dalam Susanto Budaya oganisasi adalah suatu sistem nilai, kepercayaan dan kebiasaan dalam suatu organisasi yang saling berinteraksi dengan struktur sistem formalnya untuk menghasilkan norma-norma perilaku organisasi. Menurut Ivancevich budaya organisasi yang kuat dicirikan dengan adanya karyawan yang memiliki nilai inti bersama. Semakin banyak nilai berbagi dan menerima nilai inti, semakin kuat budaya, dan semakin besar pengaruhya terhadap perilaku organisasi. Budaya organisasi meresap dalam kehidupan organisasi dan selanjutnya mempengaruhi setiap kehidupan organisasi. Oleh karena itu, budaya organisasi berpengaruh sangat besar pada aspek-aspek fundamental dari kinerja organisasi. Pernyataan tersebut telah diterima dengan luas dan didukung oleh beberapa penelitian yang menghubungkan kinerja dengan budaya organisasi. Jika budaya organisasi merupakan aspek penting dalam meningkatkan kinerja maka budaya organisasi harus dikelola dengan baik. ${ }^{2}$

Selain budaya organisasi kepuasan kerja menjadi salah satu aspek yang mempengaruhi kinerja karyawan. Sikap merupakan salah satu komponen dari modal manusia. Oleh karena itu, dalam menganalisis pegawai, aspek sikap ini harus diperhitungkan. Salah satu sikap pegawai

\footnotetext{
${ }^{1}$ Alindra, A. I. (2015). Analisis Pengaruh Budaya Organisasi Terhadap Kinerja Karyawan Depok Sports Center. 86.

${ }^{2}$ Sarwono, J. (2006). korelasi. Dipetik Februari 1, 2019, dari www.jonathansarwono.com: http://www.jonathansarwono.info/ korelasi/korelasi.htm.
} 
dalam hubungannya adalah kepuasan kerja (job satisfaction). Menurut Husain, menyatakan bahwa: Kepuasan kerja adalah perasaan dan penilaian seorang atas pekerjaannya, khususnya menegenai kondisi kerjanya, dalam hubungannya dengan apakah pekerjaannya mampu memenuhi harapan, kebutuhan, dan keinginannya. ${ }^{3}$

Kreitner dan Kinicki berpendapat bahwa kepuasan kerja adalah respons afektif atau emosional terhadap berbagai macam segi dari suatu pekerjaan. Ivancevich, Konopaske, dan Matteson Kepuasan kerja adalah sikap yang dimiliki orang-orang tentang pekerjaan mereka. ${ }^{4}$

Menurut Marihot Tua Effendi Hariandja berpendapat bahwa: Kepuasan kerja adalah merupakan salah satu elemen yang cukup penting dalam organisasi. Hal ini di sebabkan kepuasan kerja dapat mempengaruhi perilaku kerja seperti malas, rajin, produktif, dan lain - lain, atau mempunyai hubungan beberapa jenis perilaku yang sangat penting dalam organisasi. Menurut T.Hani Handoko, menyatakan bahwa : Kepuasan kerja adalah keadaan emosional yang menyenangkan atau tidak menyenangkan dimana para karyawan memanadang pekerjaan mereka. ${ }^{5}$

Dari beberapa teori diatas, dapat disimpulkan bahwa ada banyak faktor yang mempengaruhi kinerja karyawan. Salah satunya adalah budaya organisasi dan kepuasan. KSPPS Dana Ukhuwah merupakan KSPPS yang telah berdiri sejak November 1996. Dalam perjalanannya KSPPS Dana Ukhuwah ini telah memiliki satu kantor pusat dan empat kantor cabang. Kantor pusat KSPPS Dana Ukhuwah berada di kecamatan Lembang Kabupaten Bandung Barat dan sebaran cabangnya berada di Subang, Cicalengka dan Kota Bandung. KSPPS Dana Ukhuwah memiliki Produk simpanan, Produk pembiayaan dan layanan payment point. Untuk membangun citra dan pelayanan yang maksimal, maka dibutuhkan karyawan yang berkualitas pula. Budaya organisasi dan kepuasan menjadi salah satu aspek penting pembangunan kualitas karyawan. Bila budaya organisasi suatu perusahaan kuat dan karyawan memiliki kepuasan atas pekerjaannya, hal tersebut akan meningkatkan kinerja karyawan.

\footnotetext{
${ }^{3}$ Sayekti, W. D. (2011). Kompetensi, Kepuasan Kerja, Komitmen Organisasional, Motivasi dan Kinerja. Unpad Press. 213.

${ }^{4}$ Wibowo, T. A. (2008). Analisis Pengaruh Budaya Organisasi Dan Kepuasan Kerja Terhadap Motivasi Kerja Dan Kinerja Karyawan (Studi Pada Kantor Unit Cabang BRI Pattimura Semarang), 221

${ }^{5}$ Riani, A. L. (2011). Budaya Organisasi. Graha Ilmu. 16
} 


\section{LANDASAN TEORI DAN HIPOTESIS}

\section{Kinerja Karyawan}

Mangkunegara Kinerja adalah hasil kerja secara kualitas dan kuantitas yang dicapai oleh seorang pegawai dalam melaksanakan tugasnya sesuai dengan tanggung jawab yang diberikan kepadanya. ${ }^{6}$

Sedarmayanti Kinerja merupakan terjemahan dari performance yang berarti hasil kerja seorang pekerja, sebuah proses manajemen atau suatu organisasi secara keseluruhan, dimana hasil kerja tersebut harus dapat ditunjukkan buktinya secara konkrit dan dapat diukur (dibandingkan dengan standar yang telah ditentukan). ${ }^{7}$

Henry Simamora Kinerja karyawan adalah tingkat terhadap mana para karyawan mencapai persyaratan-persyaratan pekerjaan. Rivai dalam Muhammad Sandy memberikan definisi bahwa kinerja atau prestasi kerja adalah hasil atau tingkat keberhasilan seseorang secara keseluruhan selama periode tertentu di dalam melaksanakan tugas dibandingkan dengan berbagai kemungkinan, seperti standar hasil kerja, target atau sasaran atau kriteria yang telah ditentukan terlebih dahulu dan disepakati bersama. Abdullah Standar kinerja merupakan yang diharapkan suatu organisasi, dan merupakan pembanding (benchmark) tujuan atau target tergantung pada pendekatan yang diambil. Standar kinerja yang baik harus realistis, dapat diukur dan mudah dipahami dengan jelas sehingga bermanfaat bagi organisasi maupun para karyawan.

Wilson Standar kinerja adalah tingkat yang diharapkan suatu pekerjaan tertentu untuk dapat diselesaikan, dan merupakan pembanding (benchmark) atas tujuan atau target yang ingin dicapai, sedangkan hasil pekerjaan merupakan hasil yang diperoleh seorang karyawan dalam mengerjakan pekerjaan sesuai persyaratan pekerjaan atau standar kinerja.

Menurut Mathis dan Jakson, Faktor-faktor yang mempengaruhi kinerja individu karyawan, yaitu: Kemampuan mereka, Motivasi, Dukungan yang diterima, Keberadaan pekerjaan yang mereka lakukan dan Hubungan mereka dengan organisasi.

Menurut Husein, Kinerja karyawan dapat dikatakan baik atau dapat dinilai dari beberapa hal, yaitu : Kesetiaan, Kinerja dapat diukur dari kesetiaan karyawan terhadap tugas dan tanggung jawabnya dalam

\footnotetext{
${ }^{6}$ Prof. Dr. Lijan Poltak Sinambela, M. M. (2012). Kinerja Pegawai. Graha Ilmu. 211.

${ }^{7}$ Mokodampit, W. (2016). Pengaruh budaya organisasi dan kepuasan kerja terhadap kinerja karyawan pt. Pos indonesia (persero) cabang makassar. Ekonomi. 21.
}

..::: Malia: Jurnal Ekonomi Islam, Volume 10 Nomor 2 Juni 2019 :::.. 
organisasi. kesetiaan adalah tekad dan kesanggupan, menaati, melaksanakan dan mengamalkan sesuatu yang ditaati dengan penuh kesadaran dan tanggung jawab. Prestasi Kerja, Hasil prestasi kerja karyawan, baik kualitas maupun kuantitas dapat menjadi tolak ukur kinerja. Pada umumnya prestasi kerja seorang karyawan dipengaruhi oleh kecakapan, keterampilan, pengalaman, dan kesanggupan karyawan dalam melaksanakan tugas dan fungsinya.

Kedisiplinan, Sejauhmana karyawan dapat mematuhi peraturanperaturan yang ada dan melaksanakan intruksi yang diberikan kepadanya. Kreatifitas, Merupakan kemampuan karyawan dalam mengembangkan kreatifitas dan mengeluarkan potensi yang dimiliki dalam menyelesaikan pekerjaannya sehingga bekerja lebih berdayaguna dan berhasil guna. Kerjasama, Dalam hal ini kerjasama diukur dari kemampuan karyawan untuk bekerjasama dengan karyawan lain dalam menyelesaikan suatu tugas yang ditentukan, sehingga hasil pekerjaannya akan semakin baik. Kecakapan, Dapat diukur dari tingkat pendidikan karyawan yang disesuaikan dengan pekerjaan yang menjadi tugasnya. Tanggung jawab, Yaitu kesanggupan seorang karyawan menyelesaikan pekerjaan yang diserahkan kepadanya dengan sebaik-baiknya dan tepat pada waktunya serta berani memikul resiko pekerjaan yang dilakukan.

Maka dari pendapat Husein diatas, Kinerja karyawan dapat dikatakan baik atau dapat dinilai melalui tujuh aspek diatas. Semakin banyak aspek yang dipenuhi karyawan maka kinerja karyawan semakin baik. Begitupun sebaliknya, bila hanya sedikit aspek yang dapat dipenuhi, maka kinerja karyawan semakin rendah. ${ }^{8}$

\section{Budaya Organisasi}

Secara komprehensif budaya organisasi didefinisikan sebagai sebuah corak dan asumsi-asumsi dasar-ditemukan, atau dikembangkan oleh sebuah kelompok tertentu untuk belajar mengatasi problem-problem kelompok dari adaptasi eksternal dan integrai internal-yang telah bekerja dengan baik, cukup relevan untuk dipertimbangkan sebagai sesuatu yang yang benar untuk berpersepsi, berpikir dan berperasaan dalam hubungannya dengan problem-problem tersebut.

\footnotetext{
${ }^{8}$ Dani Rizki Pratama, S. D. (2014). Analisis pengaruh budaya organisasi dan kepuasan kerja terhadap kinerja karyawan bagian marketing Bank Panin Pekanbaru. 87.
}

..::: Malia: Jurnal Ekonomi Islam, Volume 10 Nomor 2 Juni 2019 :::.. 
Luthans dalam Susanto mengemukakan bahwa, budaya organisasi adalah norma-norma dan nilai-nilai yang mengarahkan perilaku anggota organisasi. Setiap anggota akan berperilaku sesuai dengan budaya yang akan berlaku agar diterima oleh lingkungannya. Dalam pendapatnya Sarplin dalam Susanto menyatakan budaya organisasi adalah suatu sistem nilai, kepercayaan dan kebiasaan dengan struktur formalnya untuk menghasilkan norma-norma perilaku organisasi. Menurut Sondang budaya organisasi adalah penggabungan antara gaya kepemimpinan manajemen puncak dan norma-norma serta sistem nilai keyakinan para anggota organisasi. Sedangkan menurut Deddy Mulyadi budaya organisasi adalah apa yang karyawan rasakan dan bagaimana persepsi ini menciptakan suatu pola teladan kepercayaan, nilai-nilai dan harapan.

Dengan demikian, kinerja karyawan perusahaan akan membaik seiring dengan internalisasi budaya organisasi. Karyawan yang sudah memahami nilai - nilai organisasi akan menjadikan nilai - nilai tersebut sebagai salah satu kepribadian organisasi. ${ }^{9}$

\section{Kepuasan Kerja}

Luthans mendifinisikan kepuasan kerja sebagai hasil persepsi pegawai tentang bagaimana pekerjaan mereka dapat memberikan sesuatu yang dianggap penting. Sedangkan menurut Minner (1988:90), kepuasan kerja seringkali disamakan dengan sikap seseorang terhadap pekerjaan. Hampir sama dengan pengertian Minner, Robbins (1996:90), menyatakan bahwa kepuasan kerja sebagai sikap secara umum dan tingkat perasaan positif seseorang terhadap pekerjaannya. ${ }^{10}$

Menurut Sutrisno kepuasan kerja adalah keadaan emosional yang menyenangkan atau tidak menyenangkan bagi para karyawan memandang pekerjaan mereka. Kepuasan kerja mencerminkan perasaaan seseorang terhadap pekerjaanya dan segala sesuatu yang dihadapi di lingkungan kerjanya. Karyawan yang tidak memperoleh kepuasan kerja tidak akan pernah mencapai kepuasan psikologis dan akhirnya akan

\footnotetext{
9 Dimyati, M. R. (2011). Analisis Pengaruh Budaya Organisasi Dan Kepuasan Kerja Terhadap Kinerja Pegawai Dengan Komitmen Organisasial Sebagai Variabel Pemedias. jurnal Bisnis Strategi. 91.

${ }^{10}$ Dimyati, M. R. Analisis Pengaruh Budaya Organisasi Dan Kepuasan Kerja Terhadap Kinerja Pegawai Dengan Komitmen Organisasial Sebagai Variabel Pemedias. jurnal Bisnis Strategi. (2011) 90
}

..::: Malia: Jurnal Ekonomi Islam, Volume 10 Nomor 2 Juni 2019 :::... 
timbul sikap atau tingkah laku negatif dan pada gilirannya akan dapat menimbulkan frustasi. Sebaliknya karyawan yang terpuaskan akan dapat bekerja dengan baik, penuh semangat, aktif, dan dapat berprestasi lebih baik dari karyawan yang tidak memperoleh kepuasan kerja.

Kepuasan kerja dapat menjadi salah satu gambaran dari perusaan karyawan terhadap pekerjaannya. Hal ini kan tampak pada karyawan yang memiliki tingkat kepuasan yang tinggi akan memperlihatkan sifat positif terhadap pekerjaannya. Sebaliknya, katyawan yang memiliki tingkat kepuasan yang rendah, akan memperlihatkan sifat negatif terhadap pekerjaannya. ${ }^{11}$

Menurut Danfar kepuasan kerja merupakan sikap positif menyangkut penyesuaian karyawan terhadap faktorfaktor yang mempengaruhinya. Adapun faktor-faktor yang mempengaruhi kepuasan kerja, meliputi: Faktor Kepuasan Finansial, yaitu terpenuhinya keinginan karyawan terhadap kebutuhan finansial yang diterimanya untuk memenuhi kebutuhan mereka sehari-hari sehingga kepuasan kerja bagi karyawan dapat terpenuhi. Hal ini meliputi : sistem, besarnya gaji, jaminan sosial, macam-macam tunjangan, dan fasilitas yang diberikan serta promosi. Faktor Kepuasan Fisik, yaitu faktor yang berhubungan dengan kondisi fisik lingkungan kerja dan kondisi fisik karyawan. Hal ini meliputi: jenis pekerjaan, pengaturan waktu kerja dan istirahat, perlengkapan kerja, keadaan ruangan atau suhu, penerangan, pertukaran udara, kondisi kesehatan karyawan dan umur. Faktor Kepuasan Sosial, yaitu faktor yang berhubungan dengan interaksi sosial baik antar sesama karyawan dengan atasannya maupun karyawan yang berbeda jenis pekerjaannya. Hal ini meliputi beberapa hal, yakni : rekan kerja, pimpinan yang adil dan bijaksana, serta pengarahan dan perintah yang wajar. Faktor Kepuasan Psikologi, yaitu berhubungan dengan kejiwaan karyawan. Hal ini meliputi: minat, ketentraman dalam bekerja, sikap terhadap kerja, bakat dan keterampilan.

Dalam bukunya menyatakan bahwa tidak diragukan lagi bahwa kepuasan kerja berhubungan signifikan terhadap kinerja pegawai. Davis dan Newstrom mengemukakan bahwa sebagian manajer berasumsi bahwa kepuasan kerja yang tinggi selamanya akan menimbulkan prestasi

${ }^{11}$ Pirzada Sami Ullah Sabri, dkk. (2011). Organizational Culture and Its Impact on the Job Satisfaction of the University Teachers of Lahore. International Journal of Business and Social Science. 
$262\}$ Analisis Strategi Pemasaran Tabungan Mabrur

yang tinggi, tetapi asumsi ini tidak benar, bukti yang memberi kesan menjadi lebih akurat bahwa produktivitas itu mungkin menimbulkan kepuasan.

Dalam kasus tertentu, ada kemungkinan terjadinya kepuasan yang tinggi namun kinerja tidak memenuhi standar. Hal ini menandakan bahwa kinerja karyawan tidak hanya dipengaruhi oleh variabel tunggal yakni kepuasan. Namun ada variabel lain yang juga mempengaruhi tingkan kinerja karyawan.

Hipotesis 1 : Budaya Organisasi secara Parsial memiliki pengaruh positif dan signifikan terhadap Kinerja Karyawan pada KSPPS Dana Ukhuwah

Hipotesis 2 : Kepuasan Kerja secara parsial memiliki berpengaruh positif dan signifikan terhadap Kinerja Karyawan pada KSPPS Dana Ukhuwah

Hipotesis 3 : Budaya Organisasi dan Kepuasan Kerja secara simultan memiliki pengaruh positif dan signifikan terhadap Kinerja Karyawan pada KSPPS Dana Ukhuwah

\section{METODOLOGI PENELITIAN}

\section{Populasi dan Sampel}

Populasi merupakan wilayah generalisasi yang terdiri atas subjek atau objek yang memiliki karakter \& kualitas tertentu yang ditetapkan oleh seorang peneliti untuk dipelajari yang kemudian ditarik sebuah kesimpulan. Populasi dari penelitian ini adalah seluruh karyawan KSPPS Dana Ukhuwah yang berjumlah 31 orang.

Sampel adalah suatu himpunan bagian (subset) dari unit populasi. Sampel adalah bagian dari suatu subjek atau objek yang mewakili populasi. Pengambilan sampel harus sesuai dengan kualitas dan karakteristik suatu populasi. Pengambilan sampel yang tidak sesuai dengan kualitas dan karakteristik populasi akan menyebabkan suatu penelitian akan menjadi biasa, tidak dapat dipercaya dan kesimpulannya pun bisa keliru. Hal ini karena tidak dapat mewakili populasi. Sampel dari penelitian kali ini adalah 29 orang karyawan KSPPS Dana Ukhuwah. 


\section{Teknik Pengumpulan Data}

Teknik pengumpulan data yang akan dilakukan dengan membagikan kuisioner kepada karyawan dengan mengambil jumlah sample dari populasi yang ditentukan. Kuesioner, yaitu suatu cara pengumpulan data yang dilakukan dengan cara mendistribusikan kuesioner kepada responden. Pada penelitian ini, kuesioner dibagikan kepada responden. Jenis kuesioner yang akan digunakan adalah kuesioner tertutup dimana responden diminta untuk menjawab pertanyaan dengan memilih jawaban yang telah disediakan dengan Skala Likert.

\section{Teknik Analisis Data}

Berdasarkan variabel - variabel indikator di atas, penulis kemudian mengembangkan menjadi instrumen penelitian yang dalam hal ini adalah pertanyaan-pertanyaan di dalam kuisioner penelitian.

Skala likert digunakan untuk mengukur sikap, pendapat, dam persepsi seseorang atau sekelompok orang tentang fenomena sosial. Sehingga untuk mengetahui pengukuran jawaban responden pada penelitian ini yang mana menggunakan instrument penelitian berupa kuisioner, penulis menggunakan metode skala likert (Likert's Summated Ratings). Dalam pengukuran jawaban responden, pengisian kuesioner tentang pengaruh budaya organisasi dan kepuasan kerja terhadap kinerja karyawan diukur dengan menggunakan skala likert, dengan tingkatan sebagai berikut: Jawaban Sangat Setuju diberi bobot 4, Jawaban Setuju diberi bobot 3, Jawaban Tidak Setuju diberi bobot 2, Jawaban Sangat Tidak Setuju diberi bobot 1

Instrumen penelitian (kuisioner) yang baik harus memenuhi persyaratan yaitu valid dan reliabel. Untuk mengetahui validitas dan reliabilitas kuesioner perlu dilakukan pengujian atas kuisioner dengan menggunakan uji validitas dan uji reliabilitas. Karena validitas dan reliabilitas ini bertujuan untuk menguji apakah kuesioner yang disebarkan untuk mendapatkan data penelitian adalah valid dan reliabel, maka untuk itu, penulis juga akan melakukan kedua uji ini terhadap instrumen penelitian (kuisioner).

Dalam mengolah data kuesioner, penulis menggunakan Software SPSS, yaitu sebuah program komputer yang digunakan untuk menganalisis data statistik. Keunggulan program ini adalah dapat 
$264\}$ Analisis Strategi Pemasaran Tabungan Mabrur

mempercepat perhitungan secara akurat. Hasil pengolahan data kuesioner melalui SPSS tersebut, akan menghasilkan distribusi frekuensi dan presentase dari pernyataan setiap indikator/pernyataan.

\section{ANALISIS DATA}

Sejarah Singkat KSPPS Dana Ukhuwah Kelahiran KSPPS Dana Ukhuwah berawal dari akan diadakannya pelatihan calon pengurus KSPPS se Jawa Barat yang diselenggarakan oleh Pusat Inkubasi Bisnis Usaha Kecil (Pinbuk)Jawa Barat bekerjasama dengan Pemda Provinsi Jawa Barat pada tanggal 18-28 Juli 1996 di Wisma Kartini Bandung.

Salah seorang pengurus Pinbuk yang berdomisili di Kecamatan Lembang, menyadari bahwa pada saat itu belum ada satu pun KSPPS di kecamatan Lembang. Maka muncul ide untuk mendirikan sebuah KSPPS di Lembang, ide tersebut kemudian disosialisasikan kepada rekannya. Pada akhirnya KSPPS Dana Ukhuwah ini berdiri dengan inisiasi: Imas Masitoh, S,Pd, Eri Endriyali. Dra , Marsadi, Drs, Eman Sulaeman, S.Ag dan Muhammad Rizani, S.Sos.

Setelah segala persiapan dirasa mencukupi, maka diputuskan bahwa KSPPS yang kemudian diberi nama KSPPS Dana Ukhuwah akan diresmikan pada tanggal 10 November 1996. Dengan harapan mampu diresmikan oleh Gubernur Jawa Barat. Namun dengan segala kondisi yang ada, tidak memungkinkan untuk diresmikan oleh Gubernur. Maka peresmian KSPPS Dana Ukhuwah dilandasi dengan syukur atas kelahirannya sebagai KSPPS pertama di kecamatan Lembang.

Pada awalnya Kelompok Swadaya Masyarakat merupakan payung yang dipilih untuk memulai aktivitas KSPPS, karena bentuk organisasi ini dirasakan tidak terlalu sulit dalam proses pembentukannya. Namun dikarenakan semakin banyak kegiatan-kegiatan yang dalam pelaksanaannya mensyaratkan adanya suatu badan hukum yang diakui oleh pemerintah, maka pada mulai tanggal 20 Februari 1999 KSPPS Dana Ukhuwah mengenakan baju Koperasi KSPPS sebagai badan hukum dengan No. 54/BH/518KOP/II/1999.

Alhamdulillah, saat ini KSPPS Dana Ukhuwah telah memiliki 2 (dua) kantor Cabang di Cicalengka dan Subang serta 1 (satu) kantor kas di Panyileukan, kabupaten Bandung. Hingga akhir tahun 2018 total asset KSPPS Dana Ukhuwah hamper menyentuh angka Rp. 20.000.000.000,00 (Dua puluh milyar rupiah). 
Visi Misi KSPPS Dana Ukhuwah Visi KSPPS Dana Ukhuwah : Menjadi Lembaga Keuangan Makro yang Kokoh dan Berskala Makro. Misi : Mensosialisasikan prinsip-prinsip ekonomi syari'ah, Menguatkan ekonomi anggota melalui pemberian modal usaha dengan menerapkan sistem keuangan syariah sehingga pada gilirannya akan dapat menumbuh kembangkan ekonomi ummat dan Menumbuhkembangkan ekonomi ummat.

\section{PEMBAHASAN}

Berdasarkan hasil analisis yang telah diuraikan sebelumnya, bahwa budaya organisasi dan kepuasan secara simultan memiliki pengaruh korelasi yang cukup terhadap kinerja karyawan sebesar 40,3\%. Budaya organisasi dalam uji parsial nya memiliki pengaruh positif dan signifikan terhadap kinerja karyawan. Hal ini dipengaruhi dengan budaya organisasi yang dimiliki perusahaan sangat kuat, dinamis dan adaptif dapat dilihat dari hasil kuisioner, bahwa budaya organisasi di KSPPS Dana Ukhuwah diterapkan dengan sangat baik. Sedangkan, sebaliknya kepuasan memiliki pengaruh terhadap kinerja karyawan namun tidak terlalu signifikan. Hal ini dipengaruhi dengan faktor kepuasan karyawan terhadap pemenuhan hak dan kewajiban karyawan.

Dari hasil yang didapatkan, memang budaya organisasi dan kepuasan memiliki pengaruh terhadap kinerja karyawan, seperti yang dijelaskan dengan wawancara oleh HRD KSPPS Dana Ukhuwah, pengaruh terhadap kinerja karyawan dapat dilihat dalam berbagai faktor, yakni:

1. Faktor kesetiaan

Dari sisi retensi keluar masuk karyawan di BMT Dana Ukhuwah sangat kecil sekali hal ini dapat dibuktikan dengan lama kerja karyawan di BMT Dana ukhuwah sampai dengan saat ini rata-rata diatas 5 tahun bahkan ada yang sampai puluhan tahun ( seusia dengan BMT Dana Ukhuwah saat ini 23 tahun), tentunya hal itu menunjukan kecintaan dan loyalitas karyawan terhadap lembaga ini

2. Faktor Prestasi kerja, faktor kreatifitas dan faktor kecakapan

Kami mencoba menyandingkan antara faktor kecakapan, faktor kreatifitas dan dan factor prestasi kerja, mengapa demikian karena melihat fakta kondisi dilapangan dan ketiga faktor tersebut saling berkaitan:

a. Jenjang pendidikan karyawan di BMT Dana Ukhuwah adalah $95 \%$ SMA, namun demikian kami melihat bahwa setiap karyawan yang ..::: Malia: Jurnal Ekonomi Islam, Volume 10 Nomor 2 Juni 2019 :::... 
bekerja di BMT Dana Ukhuwah memiliki kesempatan yang sama untuk belajar meningkatkan kualitas kerja dan mengembangkan kemampuan dirinya

b. Sosialisasi mengenai SOP dan aturan kebijakan lainnya dilakukan secara berkala agar karyawan memahami mengenai job description , tugas, wewenang hak dan kewajibannya

c. Melalui evaluasi kerja personal yang dikoordinir oleh masing-masing bagian akan memberikan masukan kepada manajemen mengenai kekurangan dan kelebihan ataupun potensi karyawan sehingga hal ini merupakan upaya agar karyawan/ti tersebut berada dibagian posisi yang tepat dan sesuai dengan kemampuannya

d. Dalam rencana kerja setiap tahunnya manajemen merencanakan peningkatan kapasitas staf melalui pelatihan - pelatihan internal maupun eksternal, ( In House Training, Seminar, workshop), ataupun kegiatan untuk meningkatkan ruhiyah karyawan, bahkan menyekolahkan karyawan yang memiliki potensi dan kinerja yang baik

e. Melibatkan karyawan dalam setiap even, untuk menambah wawasan , pengalaman dan mengembangkan kreatifitasnya

f. Hal-hal tersebut diatas merupakan upaya kami agar kami memilki karyawan yang berkualitas.

3. Faktor kedisiplinan

Faktor kedisiplinan mungkin belum bisa dikatakan ideal, namun sdh lebih dari cukup baik karena ada hal - hal tertentu yang lembaga terapkan yang masih bersifat flexible, kami lebih menekankan upaya kesadaran diri dalam bekerja sehingga karyawan diharapkan dapat memposisikan atau menempatkan dirinya dengan baik.

4. Faktor Kerjasama

Memberikan pemahaman kepada karyawan bahwa bekerja di BMT adalah membangun sebuah sistem yang berarti suatu kesatuan yang saling berhubungan satu sama lain, memilki visi dan misi yang sama untuk mencapai tujuan bersama, sehingga kami menyadari bahwa kami harus bekerjasama secara tim, harus berkoordinasi, menjaga komunikasi yang baik, dengan rekan kerja, atasan , stake holder ( lembaga mitra, anggota) dan masyarakat sehingga keberhasilan yang kami dapatkan adalah hasil kerjasama tim. 
5. Faktor tanggung Jawab

Karyawan sudah terbiasa melakukan pekerjaan sesuai dengan intruksi,berdasarkan ketepatan waktu dan target karena hal tersebut dilakukan monitoring dan evaluasi oleh kepala bagiannya masing masing dengan penuh tanggung jawab dan konsekuensi atas setiap pekerjaan.

\section{KESIMPULAN}

Budaya organisasi dan kepuasan karyawan memiliki pengaruh yang sangat penting bagi kinerja karyawan. Oleh karena itu, penulis melakukan penelitian terhadap pengaruh budaya organisasi dan kepuasan terhadap kinerja karyawan di KSPPS Dana Ukhuwah. Berdasarkan analisis data yang telah dilakukan, dapat disimpulkan bahwa:

Budaya organisasi (X1) berpengaruh positif dan signifikan terhadap kinerja karyawan (Y) secara parsial. Dengan nilai sig dari variabel budaya organisasi (X1) adalah 0,006 atau < dari 0,05. Dan nilai thitung sebesar 2.997 $>$ ttabel yakni 2.056 .

Kepuasan (X2) tidak berpengaruh positif dan signifikan terhadap kinerja karyawan $(\mathrm{Y})$ secara parsial. Dengan nilai sig dari variabel kepuasan (X2) adalah 0,240 atau > dari 0,05. Nilai thitung sebesar $1.202<$ ttabel yakni 2.056 .

Budaya organisasi (X1) dan Kepuasan (X2) memiliki pengaruh yang cukup terhadap kinerja karyawan secara simultan. Dengan nilai sig adalah 0,001 atau lebih kecil dari $<0.05$ dan nilai dari Fhitung adalah $8.780>$ Ftabel yaitu 3.35.

\section{DAFTAR PUSTAKA}

Alindra, A. I. (2015). Analisis Pengaruh Budaya Organisasi Terhadap Kinerja Karyawan Depok Sports Center.

Dani Rizki Pratama, S. D. (2014). Analisis pengaruh budaya organisasi dan kepuasan kerja terhadap kinerja karyawan bagian marketing Bank Panin Pekanbaru.

Dimyati, M. R. (2011). Analisis Pengaruh Budaya Organisasi Dan Kepuasan Kerja Terhadap Kinerja Pegawai Dengan Komitmen Organisasial Sebagai Variabel Pemedias. jurnal Bisnis Strategi. 
$268\}\{$ Analisis Strategi Pemasaran Tabungan Mabrur

Mokodampit, W. (2016). Pengaruh Budaya Organisasi Dan Kepuasan Kerja Terhadap Kinerja Karyawan PT. Pos Indonesia (persero) cabang Makassar. Ekonomi.

Pirzada Sami Ullah Sabri, dkk. (2011). Organizational Culture and Its Impact on the Job Satisfaction of the University Teachers of Lahore. International Journal of Business and Social Science.

Prof. Dr. Lijan Poltak Sinambela, M. M. (2012). Kinerja Pegawai. Graha Ilmu.

Prof. Dr. Sondang P. Siagian, M. (2004). Manajemen Internasional. Bumi Aksara.

Riani, A. L. (2011). Budaya Organisasi. Graha Ilmu.

Sarwono, J. (2006). korelasi. Dipetik Februari 1, 2019, dari www.jonathansarwono.com: http://www.jonathansarwono.info/ korelasi/korelasi.htm

Sayekti, W. D. (2011). Kompetensi, Kepuasan Kerja, Komitmen Organisasional, Motivasi dan Kinerja. Unpad Press.

Taurisa, C. M. (2012). Analisis Pengaruh Budaya Organisasi Dan Kepuasan Kerja Terhadap Komitmen Organisasional Dalam Meningkatkan Kinerja Karyawan (Studi pada PT. Sido Muncul Kaligawe Semarang). Wibowo, T. A. (2008). Analisis Pengaruh Budaya Organisasi Dan Kepuasan Kerja Terhadap Motivasi Kerja Dan Kinerja Karyawan (Studi Pada Kantor Unit Cabang BRI Pattimura Semarang). 